\title{
PEDOGEOGRAFSKA REGIONALIZACIJA POMURSKE RAVNINE
}

\author{
Franc Lovrencak *
}

\section{IZVLEČEK}

UDK 911.62:631.4(497.12-18)

Članek obravnava pedogeografsko regionalizacijo Pomurske ravnine (Severovzhodna Slovenija). Na osnovi razlik $\mathbf{v}$ matǐ̌ni kamnini, reliefu in vodnih znacilnostih pripada odeja prsti dvema pedogeografskima regijama. Vsaka od teh regij se deli še na vex̌ podregij, ki zajemajo sorodne skupine prsti.

UDC 911.62:631.4(497.12-18)

\section{ABSTRACT}

PEDOGEOGRAPHIC REGIONALIZATION OF THE POMURJE PLAIN

The paper deals with the pedogeographic regionalization of the Pomurje plain (Northeast Slovenia). With regard to differences in parent material, landforms, and hydrographic characteristics, the soil cover is ranked into two pedogeographic regions. Each of them is furthermore divided into several subregions grouped together according to related soil groups.

Pomurska ravnina zajema ves ravninski svet na levem in desnem bregu Mure; na levi strani Ravensko in Dolinsko ter na desni strani Mure Mursko polje in spodnji del doline Šcavnice (Ilesix, 1967, 1981; Gams, 1983). V tem prispevku ne bo zajeto Apasko polje, ki po teh regionalizacijah tudi sodi $\mathbf{k}$ Pomurski ravnini.

Ravnino gradijo pleistocenski in holocenski nanosi Mure, Ledave Šcavnice in njihovih pritokov. Ob Muri jo pretežno sestavljajo nekarbonatni prod in pesek. $\mathrm{V}$ dolinah ob pritokih so rumenorjave in rdečkaste peš̌ene ilovice (Gregorið, 1984). Povrక̌je večinoma pripada holocenski ravnini, ki je najobsežnejša ob Muri. Ta ravnina ni razrezana v terase (Gams, 1959). Nad holocensko ravnino se na obrobju dvigajo pleistocenske terase $\mathrm{v}$ veð loðenih delih: na severni strani pod Gorickim Cankovska in Sebeborska terasa, na južni strani pod Slovenskimi goricami Radenska in ob Medžimurskih goricah Šmartinska terasa (Gams, 1959).

Pleistocenske terase Gregoriðeva (1984) uvrš̌a v starejšo (približno do nad. v. $250 \mathrm{~m}$ ) in mlajso ali nižjo ( $v$ nad. v. $215-230 \mathrm{~m}$ ).

Starejso teraso sestavljajo kremenov prod s polami kremenovega peska in lecami gline. Prod je prekrit s sest metrov debelo plastjo ilovice. Tudi mlajšo teraso prekrivajo tri do pet metrov debele plasti ilovice, pod njo leži nečist prod, ki se menjava z rjavim kremenovim peskom in lecami sivomodre gline (Gregoric, 1984).

* Dr, izr. univ. prof, Oddelek za geografijo, Filozofska fakulteta, Univerza v Ljubljani, Aškerčeva 12, 61000 Ljubljana, Slovenija. 
Taka maticna osnova in reliefna izoblikovanost izrazito vplivata na vodne razmere Pomurske ravnine.Poplavna in talna voda sta bili odlocilni za nastanek in razvoj hidromorfnih prsti, ki prekrivajo obsežne dele ravnine. Manjše dele ravnine prekrivajo prsti na katere vpliva le padavinska voda, ki se neovirano pretaka skozi profil prsti v talno vodo.

Razlike $\mathbf{v}$ reliefni izoblikovanosti, maticni osnovi in vodnih značinostih so vplivale na razlike $\mathbf{v}$ sestavi odeje prsti, ki jo sestavlja veð pedogeografskih enot. Namen tega prispevka je pokazati raznolikosti Pomurske ravnine prav na osnovi razlik v njeni odeji prsti. Pedogeografska regionalizacija naj bi pomagala tudi pri kompleksni naravnogeografski regionalizaciji tega dela Severovzhodne Slovenije.

Pri izlođanju pedogeografskih enot smo se oprli na pedološko karto Murska Sobota in njen komentar (Stepancič, 1984). Pri tem delu gre za individualno razvrš̌anje manjsih enot v večje - in enostavno pedogeografsko regionalizacijo. Enostavna je zato, ker pri opredeljevanju regij nismo uporabili zonalnih (bioklimatskih) kriterijev, temvec le intrazonalne (relief-kamninska osnova-voda). Na Pomurski ravnini ni tako velikih razlik v podnebju, da bi ta pokrajinski dejavnik odloxilno vplival na razlike v odeji prsti. Po Gamsu (1972) spada celotno Pomurje v spodnjepodravsko-pomurski podnebni rajon obmoxja s subpanonskim podnebjem.

Kriteriji za razmejevanje posameznih pedogeografskih regij so bile razlike $\mathrm{v}$ naravnogeografskih dejavnikih Pomurske ravnine. Uporabljena je bila pot "od zgoraj navzdol", kjer je bila v ospredju reliefna razlixnost in "od spodaj navzgor", ko smo združevali razlið̌ne pedosistematske enote.

Na osnovi razlik v sestavi odeje prsti Pomurske ravnine se po teh kriterijih kažeta dve pedogeografski regiji:

I. prsti na holocenski ravnini

II. prsti na pleistocenskih terasah

Prva regija ima Sest podregij: 1. ravnina ob Muri, 2. ravnina med Muro in Ledavo, 3. ravnina ob Ledavi, 4. ravnina ob Šcavnici, 5.ravnice ob pritokih Ledave in Šcavnice iz Gorickega ter Slovenskih goric, 6. ravnina Genterovskega pretržaj.

Prva podregija zajema vse obrecne prsti na recentnih rečnih nanosih na holocenski ravnini ob Muri. Po globini so plitve do globoke, po teksturi pešene, ilovnate do meljnato glinasto ilovnate. Sem sodijo tudi srednje globoke do globoke oglejene obrěne prsti, kjer pride že do mox̌nejšega vlaženja spodnjega dela profila, po teksturi so meljnato ilovnate. Njive so na obrečnih plitvih in neoglejenih prsteh, travniki pa na ilovnato-meljnato ilovnatih, srednje globoko ogle jenih prsteh. 


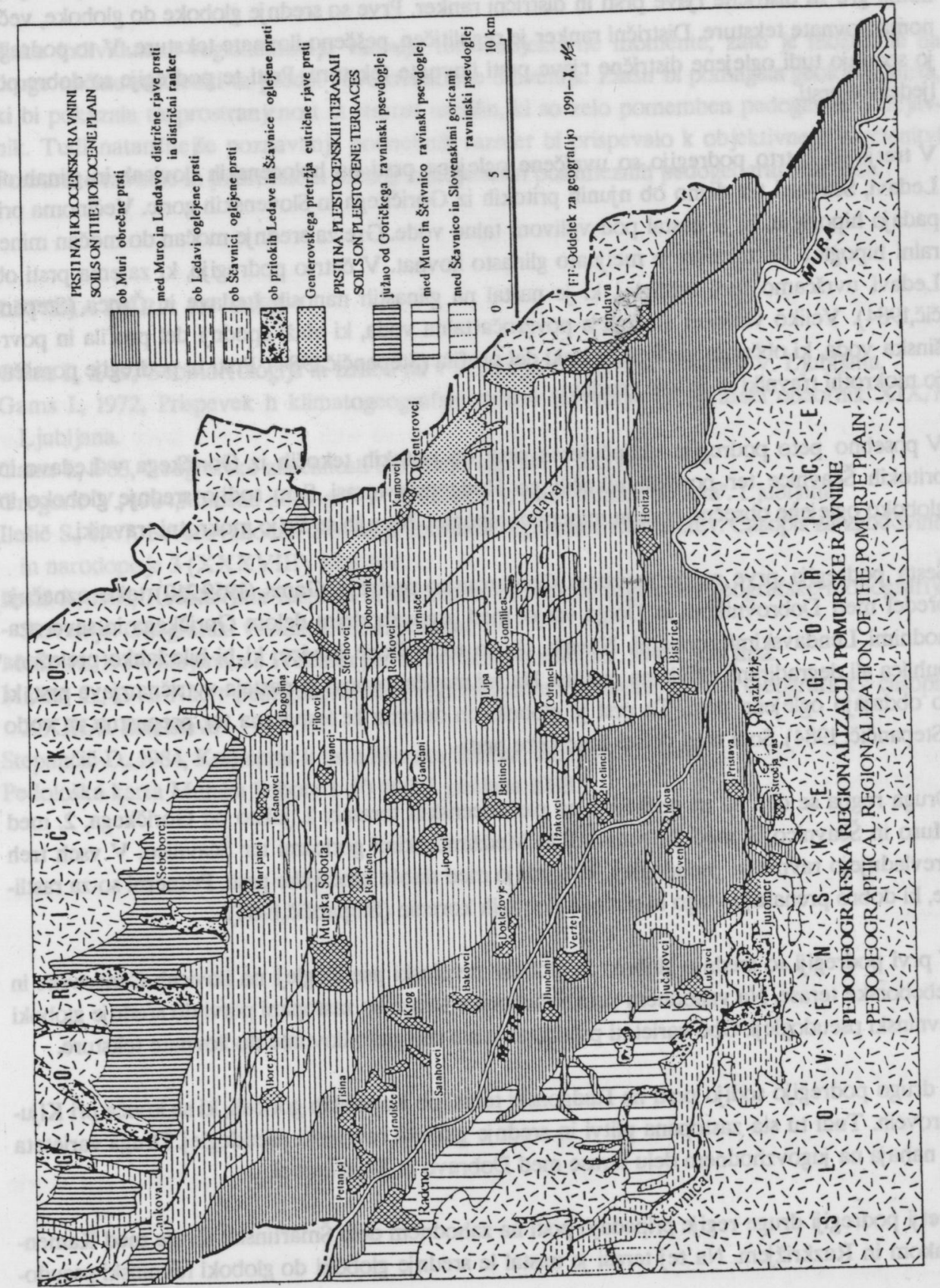


V drugo podregijo spadajo prsti na holocenskem produ in pesku med Muro in Ledavo. Vecinoma gre za distrixne rjave prsti in distrixni ranker. Prve so srednje globoke do globoke, večinoma ilovnate teksture. Distrični ranker je regolitǐen, pešeno ilovnate teksture. $\mathrm{V}$ to podregijo spadajo tudi oglejene districne rjave prsti ilovnate teksture. Prsti te podregije so dobre poljedelske prsti.

$\mathrm{V}$ tretjo in cetrto podregijo so uvršcene oglejene prsti na holocenskih ilovicah in glinah ob Ledavi, Ščavnici ter delno ob njunih pritokih iz Gorickega in Slovenskih goric. Vecinoma pripadajo hipogleju, ki je nastal pod vplivom talne vode. Gre za srednje moxan do moxan mineralni hipoglej. Po teksturi je meljnato glinasto ilovnat. $\mathrm{V}$ cetrto podregijo, ki zajema prsti ob Ledavi uvrš̌amo tudi amfiglej, ki je nastal na glinastih nanosih Ledave in Črnca (Stepancič,1984). Veliko vlažnost amfigleja povzrođa talna voda, ki vlaži spodnji del profila in povrŠnska voda, ki občasno vlaži povrకinski del profila (Stepanđič,1984). Prsti te podregije poraš̌ajo mokrotni travniki in jelševi gozdovi.

V posebno peto podregijo vključjemo prsti ob potokih tekoxih iz Goriðkega v Ledavo in pritokih Šcavnice ter potokih tekoxih po Radgonski terasi. Sem sodijo srednje globoko in globoko oglejene obrečne prsti in mineralni hipoglej. Na njih se sirijo mokrotni travniki.

Šesta podregija prve regije zavzema Genterovsko pretržje. Gams $(1959,210)$ tako označuje predel med Dobrovnikom in Dolgo vasjo, med jugovzhodnim delom Gorickega in severozahodnimi Lendavskimi goricami. Navaja, da so tu pešcene ilovice, ki bi bile lahko preložena puhlica ali degradirana eluvialna puhlica. Na tej matični osnovi je nastala evtrična rjava prst, ki jo obdajajo oglejene prsti. Ta prst je globoka in deloma že lesivirana ter prepustna za vodo (Stepanzix, 1984). Sodi med dobre kmetijske prsti.

Druga regija se deli na tri podregije na pleistocenskih terasah: 1. južno od Goriłkega, 2. med Muro in Šcavnico, 3. med Slovenskimi in Medžimurskimi goricami ter Š̌avnico. V vseh treh prevladujejo ravninski pseudogleji, ki spadajo med slabక̌ kmetijske prsti. Primerni so za rastline, ki dobro prenašajo vlago in nimajo globokih korenin (Stepanzič,1984).

V prvi podregiji so srednje globoki in globoki ravninski pseudogleji na ilovicah Cankovske in Sebeborske terase. Na vzhodnem delu Sebeborske terase so zastopani plitvi do srednje globoki ravninski pseudogleji. Obe varieteti pseudogleja sta meljnato ilovnate do ilovnate teksture.

V drugo podregijo sodijo prsti na Radgonski terasi ob Kapelskih goricah, ki se konca pri Kljucarovcih. Tudi tu sta zastopana plitvi in srednje globoki ravninski pseudoglej. Druga varieteta se nahaja na jugovzhodnem delu terase med Dobravo in Ključarovci.

Tretji podregiji druge regije pripadajo prsti na zahodnem delu Šmartinske terase med Kamenšakom in Razkrižjem. Na tej terasi je nastal le srednje globoki do globoki ravninski pseudo- 
glej, meljnato ilovnate do ilovnate teksture.

Taka individulana regionalizacija vsebuje tudi subjektivne momente, zato je možno se na druge načine ražlleniti ta predel Severovzhodne Slovenije. Zlasti bi pomagala geoloska karta, ki bi pokazala razprostranjenost in starost usedlin, ki so zelo pomemben pedogenetski dejavnik. Tudi natančnejše poznavanje podnebnih razmer bi prispevalo $\mathbf{k}$ objektivnejß̧i razčlenitvi Pomurske ravnine in podrobne jłi razlagi zastopanosti posameznih pedogeografskih enot.

\section{LITERATURA IN VIRI}

Gams I., 1959, Geomorfologija in izraba tal v Pomurju. Geografski zbornik V. L jubljana.

Gams I., 1972, Prispevek h klimatogeografski delitvi Slovenije. Geografski obzornik XIX/1. Ljubljana.

Gams I., 1983, Geografske znacilnosti Slovenije, str. 100. Ljubljana.

Gregorix V., 1984,Matix̌na podlaga - v "Komentar k listu Murska Sobota". Ljubljana.

Ilesix S., 1967, Severovzhodna Slovenija in njena regionalna razčlenitev. Časopis za zgodovino in narodopisje 3 (XXXVIII). Maribor.

Ileši S., 1981, Redakcijska zasnova in struktura predvidene regionalnogeografske monografije Slovenije. Geografski vestnik LIII. Ljubljana.

Melik A., 1957, Štajerska s Prekmurjem in Mežisko dolino, str. 594. Ljubljana.

Mičan L., 1971, Načrt pedogeografickej regionalizacie Zahorskej nižiny. Geograficky casopis XXIII/2. Bratislava

Stepancix D., 1984, Komentar k listu Murska Sobota, str. 64. Ljubljana.

Pedoloska karta Murska Sobota 1: 50 000. Ljubljana 1983. 


\section{PEDOGEOGRAPHIC REGIONALIZATION OF THE POMURJE PLAIN}

This paper deals with the diversity of the Pomurje plain considering the differences in its soil cover. These differences have been the result of various natural geographic factors.

The plain is composed of Pleistocene and Holocene sediments of the Mura, Ledava and Šcavnica rivers and their tributaries. Along the Mura, the Holocene plain is composed of non-carbonate gravel and sand. In the valleys along the tributaries, sandy silt can be found. The Holocene plain is not dissected into terraces. On the margins above the Holocene plain there rise Pleistocene terraces. Some of these are older origin ( $250 \mathrm{~m}$ above sea level) and some are of younger origin (215-230 $\mathrm{m}$ above sea level).

The older terrace is composed of silicious gravel and clay. The gravel is covered with $6 \mathrm{~m}$ thick layer of silt. The younger terrace is also covered with $3-5 \mathrm{~m}$ thick layer of silt under which impure gravel is to be found.

This type of parent material and landforms exert a marked influence on hydrologic characteristics. The greater part of the plain is covered with hydromorphic soils which are the result of innundation and underground waters' activity, while the lesser part of the plain is covered with soils which are influenced by the atmospheric water.

The versatility of landforms, parent material and hydrologic characteristics resulted in variety of composition of the soil cover. It consists of several pedosystematic units which have been defined in pedogeographic regionalization. This regionalization has been individual and simple. Landforms are an important factors of differentiation of soils. As for the soils, groups have been formed according to related soil groups.

When differences of soil cover are taken into account, two pedogeographic regions become evident:

I - soils on the Holocene plain

II - soils on the Pleistocene terraces

The first region comprises six subregions:

1. the plain along the Mura, covered with fluvisols

2. the plain between the Mura and the Ledava, covered with distric cambisols and distric rankers

3. the plain along the Šcavnica

4. the plain along the Ledava 